\title{
Facilitating Administrative Agency Access to Grand Jury Material*
}

In the course of their civil law enforcement efforts, administrative agencies frequently seek materials that were presented to federal grand juries. Agencies request these materials, which include witness transcripts, subpoenaed documents, and government memoranda, to conserve resources by obviating the need for repetitious administrative investigations. ${ }^{1}$ Grand jury proceedings are secret, ${ }^{2}$ however, and access to these materials is restricted by Federal Rule of Criminal Procedure 6(e). ${ }^{3}$ This Rule states

* The authors wish to thank Mr. Charles Walsh, who first drew their attention to the problem addressed in this Note.

1. Agency requests for grand jury materials have attracted much judicial attention during the past year. The United States Supreme Court has granted certiorari in a case involving an Internal Revenue Service (IRS) request: In re Special Feb., 1975 Grand Jury, 662 F.2d 1232 (7th Cir. 1981), cert. granted sub nom. United States v. Baggot, 102 S. Ct. 2955 (1982) (No. 81-1938). In addition, the Judicial Conference of the United States has proposed changes to the Federal Rule of Criminal Procedure governing agency access to grand jury materials. See infra note 78.

2. Although grand jury investigations are conducted in secrecy, see infra pp. 1618-19, agencies often learn about such proceedings. In the vast majority of cases, federal agents conduct extensive investigations before the evidence is presented to a grand jury. Usually a United States Attorney, with the assistance of other federal agents, will construct the bulk of his case before seeking an indictment from the grand jury. For example, in the formative stages of a case, the federal agents may gather information through search warrants. These warrants are court documents and are generally available for public (and agency) inspection. Often agencies themselves instigate grand jury investigations by bringing matters uncovered during agency inquiries to the United States Attorney's attention. Furthermore, United States Attorneys increasingly request agency assistance in presenting cases to grand juries, thereby revealing some information about ongoing investigations. See infra note 21 (discussing provision under which United States Attorneys may obtain such assistance).

"Leaks" are not uncommon. Grand jury witnesses are under no obligation of secrecy. The media commonly uncover and report about inquiries into organized crime and political corruption. Also, the United States Attorney might disclose some information about an ongoing investigation to prevent interim harms. For example, disclosing that a particular investment scheme is under grand jury investigation will warn potential victims about its possible risk. Interviews with Jeremiah Donovan and Kurt Zimmerman, Assistant United States Attorneys, District of Connecticut, in New Haven, Connecticut (Feb. $2 \& 12,1982$ ) [hereinafter cited as Interviews].

When a grand jury returns an indictment, of course, targets and charges are identified publicly. An agency then will know whether obtaining access to grand jury materials will aid subsequent agency investigations.

3.' Rule 6. The Grand Jury

...

(c) Recording and Disclosure of Proceedings

(2) General Rule of Secrecy.-A grand juror, an interpreter, a stenographer, an operator of a recording device, a typist who transcribes recorded testimony, an attorney for the government, or any person to whom disclosure is made under paragraph (3)(A)(ii) of this subdivision shall not disclose matters occurring before the grand jury, except as otherwise provided for in these rules. No obligation of secrecy may be imposed on any person except in accordance with this rule. A knowing violation of Rule 6 may be punished as a contempt of court.

(3) Exceptions.

(A) Disclosure otherwise prohibited by this rule of matters occurring before the grand jury, other than its deliberations and the vote of any grand juror, may be made to- 


\section{that "matters occurring before the grand jury" may not be disclosed unless pursuant to specified exceptions." \\ Administrative agencies usually base their disclosure requests on an ex- ception to the rule of secrecy that permits disclosure "when so directed by a court preliminarily to or in connection with a judicial proceeding."}

and

(i) an attorney for the government for use in the performance of such attorney's duty;

(ii) such government personnel as are deemed necessary by an attorney for the government to assist an attorney for the government in the performance of such attorney's duty to enforce federal criminal law.

(B) Any person to whom matters are disclosed under subparagraph (A)(ii) of this paragraph shall not utilize that grand jury material for any purpose other than assisting the attorney for the government in the performance of such attorney's duty to enforce federal criminal law. An attorney for the government shall promptly provide the district court, before which was impaneled the grand jury whose material has been so disclosed, with the names of the persons to whom such disclosure has been made.

(C) Disclosure otherwise prohibited by this rule of matters occurring before the grand jury may also be made-

(i) when so directed by a court preliminarily to or in connection with a judicial proceeding; or

(ii) when permitted by a court at the request of the defendant, upon a showing that grounds may exist for a motion to dismiss the indictment because of matters occurring before the grand jury.

If the court orders disclosure of matters occurring before the grand jury, the disclosure shall be made in such manner, at such time, and under such conditions as the court may direct.

....

Rule 6(e) does not impose an obligation of secrecy upon grand jury witnesses. A witness may disclose, publicly or privately, both his own testimony and whatever information was revealed to him in the course of his examination before the grand jury.

4. FED. R. CRIM. P. 6(e)(2). If the requested materials do not constitute "matters occurring before the grand jury," then they are not subject to the secrecy requirement. A body of case law permitting disclosures has developed around this phrase. The leading case is United States v. Interstate Dress Carriers, Inc., 280 F.2d 52 (2d Cir. 1960), wherein the court declared:

[I]t is not the purpose of the Rule to foreclose from all future revelation to proper authorities the same information or documents which were presented to the grand jury. Thus, when testimony or data is sought for its own sake-for its intrinsic value in the furtherance of a lawful investigation-rather than to learn what took place before the grand jury, it is not a valid defense to disclosure that the same information was revealed to a grand jury or that the same documents had been, or were presently being, examined by a grand jury.

Id. at 54 (citations omitted).

Disclosure on grounds of "intrinsic value" has been allowed infrequently. The few recent cases permitting such disclosure include In re Grand Jury Investigation of Uranium Indus., 1979-2 Trade Cas. (CCH) II 62,798 (D.D.C. 1979); In re Grand Jury Investigation of Ven-Fuel, 441 F. Supp. 1299 (M.D. Fla. 1977); United States v. Saks \& Co., 426 F. Supp. 812 (S.D.N.Y. 1976). The first two cases involved disclosure requests of congressional committees; the third case dealt with a Federal Trade Commission (FTC) request. In each instance only documents, not testimony, were released.

The Judicial Conference of the United States is currently considering amendments to rule $6(\mathrm{e})$ that would overrule the lenient "intrinsic value" disclosure doctrine. See infra note 78.

5. FED. R. CRIM. P. 6(e)(3)(C)(i). Three other exceptions to the rule of secrecy are set forth in rule $6(\mathrm{e})$. First, rule $6(\mathrm{e})(3)(\mathrm{A})(\mathrm{i})$ permits access to grand jury material by an "attorney for the government for use in the performance of such attorney's duty." This exception to grand jury secrecy has been construed to apply to those persons named in Federal Rule of Criminal Procedure 54(c), which defines "attorney for the government" as "the Attorney General, an authorized assistant of the Attorney General, a United States Attorney, [or an] authorized assistant of a United States Attorney . . . " See In re Grand Jury, 583 F.2d 128, 130 (5th Cir. 1978); United States v. General Elec. Co., 209 F. Supp. 197, 199-202 (E.D. Pa. 1962). But see Sells, Inc. v. United States, 642 F.2d 1184, 1188-90 (9th Cir. 1981) (holding that attorneys in United States Attorney's civil division are not "attorney[s] 
Courts have interpreted this exception to require demonstration of a "particularized" and/or a "compelling" need for disclosure that outweighs the need for grand jury secrecy. ${ }^{8}$ Often, however, courts deny the disclosure requests of administrative agencies for one or both of the following reasons: 1) administrative agency proceedings are not "judicial," and 2) administrative agency proceedings are not "preliminary to" judicial proceedings. Thus, the issue of whether an agency has demonstrated the requisite need is often not reached.

This Note argues that the "preliminarily to or in connection with a judicial proceeding" provision " of Rule 6(e) does not adequately balance the goals served by agency access against those promoted by grand jury secrecy. It shows that the framers of the "judicial proceeding" provision did not consider the issue of administrative agency access to grand jury materials and that courts have applied this provision to agencies in an inconsistent and sometimes undesirable manner. The Note suggests amending Rule 6(e) to allow a case-by-case analysis of disclosure re-

for the government"), cert. granted sub nom. United States v. Sells Eng'g, Inc., 102 S. Ct. 2034 (1982) (No. 81-1032).

The rule refers only to attorneys for the federal government and not to state or municipal attorneys. Jachimowski v. Conlisk, 490 F.2d 894, 896 (7th Cir. 1973) (citing cases). Attorneys for federal administrative agencies similarly are not included among those who might be given access under the "attorney for the government" standard of rule 6(e)(3)(A)(i). In re Grand Jury Proceedings, 309 F.2d 440, 443 (3d Cir. 1962); In re Grand Jury Investigation, 414 F. Supp. 74, 76 (S.D.N.Y. 1976). Attorneys for corporations owned by the United States are also excluded from the scope of this standard. United States v. General Elec. Co., 209 F. Supp. 197, 202 (E.D. Pa. 1962) (disclosure denied to attorneys for Tennessee Valley Authority).

Second, rule $6(\mathrm{e})(3)(\mathrm{A})(\mathrm{ii})$ permits access to grand jury material to administrative agency personnel who assist the United States Attorney in preparing criminal cases. This exception was added in 1977 to allow federal prosecutors to use the expertise of agency personnel in the grand jury investigations of sophisticated white collar crime. See infra note 21.

Finally, rule $6(\mathrm{e})(3)(\mathrm{C})(\mathrm{ii})$ permits disclosure by the court to a defendant who demonstrates that "grounds may exist for a motion to dismiss the indictment because of matters occurring before the grand jury:"

6. The Supreme Court's statements regarding the "particularized" and "compelling" need requirement were put forward in cases where disclosure was sought by private litigants. See Douglas Oil Co. v. Petrol Stops Northwest, 441 U.S. 211, 222 n.12 (1979) (applying "particularized need" standard to private plaintiffs in civil antitrust action); Pittsburgh Plate Glass Co. v. United States, 360 U.S. 395, 400 (1959) (applying "particularized need" standard to defendants in criminal price-fixing action); United States v. Proctor \& Gamble Co., 356 U.S. 677, 682 (1958) (applying "compelling necessity" standard to defendants in civil antitrust suit). Private litigants must demonstrate a compelling need for disclosure that outweighs the public interest in grand jury secrecy. In addition, disclosure requests from private litigants must be "particular," so that grand jury secrecy may be lifted discretely and narrowly. The Court has never addressed the issue of whether a public agency must meet the same standard as a private litigant. See infra notes 17,90 .

Some lower courts have blurred the distinction between "compelling" and "particularized" need, suggesting that meeting either standard may justify disclosure. See United States v. Brummitt, 503 F. Supp. 852, 854 (W.D. Tex. 1980) (disclosure requires "showing of particularized need or compelling necessity"), aff'd, 665 F.2d 521 (5th Cir. 1981), cert. denied, 102 S. Ct. 2244 (1982); United States v. Shober, 489 F. Supp. 393, 410 (E.D. Pa. 1979); Alexander v. National Farmers Org., 454 F. Supp. 281, 285 (W.D. Mo. 1978); cf. In re Grand Jury Witness Subpoenas, 370 F. Supp. 1282, 1286 (S.D. Fla. 1974) (disclosure requires "particularized need amounting to a compelling necessity").

7. FED. R. CRIM. P. 6(e)(3)(C)(i). 
quests, balancing the need for grand jury secrecy against the sometimes compelling need for agency access.

\section{The Tension Between Grand Jury Secrecy and Agency Access}

Administrative agency requests for grand jury materials create a tension between the need for grand jury secrecy and the need for agency access to information. When a court denies an administrative agency's request for grand jury materials, grand jury secrecy is preserved but inefficiency results, because agencies are forced to use their resources to do work that has already been done. Granting agency requests for grand jury material, on the other hand, promotes efficiency but may reduce the efficacy of future grand juries.

\section{A. The Need for Grand Jury Secrecy}

The grand jury is frequently described as an institution designed to function both as a "shield" and a "sword." It functions as a shield by screening the prosecutor's case to ascertain whether there is sufficient evidence to justify bringing charges against the accused. ${ }^{\circ}$ The grand jury also serves as a sword, combating crime through the use of its investigative authority. In this role, it seeks to uncover evidence and thereby to increase the likelihood of successful prosecutions. ${ }^{10}$

The grand jury is granted a wide range of powers with which to carry out these functions. ${ }^{11}$ It may, for example, compel the production of evidence and the testimony of witnesses without regard to the procedural and evidentiary rules that govern criminal trials. ${ }^{12}$ Also, grand jury witnesses

8. See United States v. Cox, 342 F.2d 167, 186 n.1 (5th Cir.) (Wisdom, J., concurring), cert. denied, 381 U.S. 935 (1965); see also United States v. Dionisio, 410 U.S. 1, 17 (1973) (describing grand jury's role as "protective bulwark" between ordinary citizen and overzealous prosecutor).

9. See In re Dymo Industries, 300 F. Supp. 532, 535 (N.D. Cal.) ("The very existence of the grand jury process serves as a deterrent against unwarranted accusations by the prosecuting agency."), aff', 418 F.2d 500 (9th Cir. 1969), cert. denied, 397 U.S. 937 (1970). But see Hawkins v. Superior Court, 22 Cal. 3d 584, 589, 586 P.2d 916, 919, 150 Cal. Rptr. 435, 438 (1978) ("[T]hough legally free to vote as they please, grand jurors virtually always assent to the recommendations of the prosecuting attorney ...."). For a summary of the debate over the effectiveness of the grand jury in reviewing the prosecutor's evidence, sce Y. KAMISAR, W. LAFAVE \& J. ISRAEL, MODERN CRIMINAL PROCEDURE 1019-22 (5th ed. 1980).

10. See Y. KAMISAR, W. LAFAVE \& J. ISRAEL, supra note 9, at 712. See generally id. at 713 (discussing special effectiveness of grand jury investigations into such areas as political corruption, price fixing, gambling and narcotics distribution).

11. See United States v. Calandra, 414 U.S. 338, 343 (1974) (Grand jury is "grand inquest, a body with powers of investigation and inquisition, the scope of whose inquiries is not to be limited narrowly ... . .) (quoting Blair v. United States, 250 U.S. 273, 282 (1919)); Branzburg v. Hayes, 408 U.S. 665, 688 (1972) ("Because [the grand jury's] task is to inquire into the existence of possible criminal conduct and to return only well-founded indictments, its investigative powers are necessarily broad."). See generally M. FRANKEL \& G. NAFTALIS, THE GRAND JURY 52-59 (1977) (discussing grand jury's wide range of powers and potential for oppression).

12. See, e.g., United States v. Dionisio, 410 U.S. 1, 15 (1973) (grand jury may act on tips, ru- 
are subjected to the psychological pressure of grand jury interrogation without the benefits of such procedural protections as the representation of counsel ${ }^{13}$ and the right to transcripts. ${ }^{14}$

The Supreme Court has recognized consistently that ongoing grand jury proceedings must be kept secret. ${ }^{15}$ It has noted several distinct interests served by safeguarding the confidentiality of such proceedings. Grand jury secrecy encourages witnesses, who might otherwise be hesitant, to appear voluntarily before the grand jury. Similarly, secrecy protects witnesses from retribution and inducements to perjury, thereby promoting full and frank disclosure. Secrecy minimizes the disclosure of information to grand jury targets, making flight less likely. It also prevents the importuning of individual grand jurors to vote against the indictment. Finally, secrecy assures that persons who are accused but ultimately not indicted will not be subjected to unfavorable publicity.

Courts have noted, however, that some of the interests served by grand jury secrecy become less important after the grand jury investigation has ended and the accused has been either exonerated or indicted and arrested. ${ }^{16}$ There is then no longer a risk that witnesses before the grand jury will be improperly influenced or that the grand jury itself will be inhibited from pursuing its investigation. In addition, the probability that an accused will flee diminishes after his arrest. For these reasons, the Supreme Court has held that a party seeking disclosure of grand jury materials need satisfy a lesser burden after the grand jury investigation has been completed. ${ }^{17}$

mors, or personal knowledge of its members); Costello v. United States, 350 U.S. 359, 363 (1956) (grand jury may consider hearsay evidence); Hale v. Henkel, 201 U.S. 43, 65 (1906) (grand jury target need not be formally charged for investigation to proceed); In re Horowitz, 482 F.2d 72, 79-80 (2d Cir.) (grand jury may subpoena material having "conceivable relevance to any legitimate object of investigation"), cert. denied, 414 U.S. 867 (1973); United States v. United States Dist. Court, 238 F.2d 713, 719-20 (4th Cir. 1956) (grand jury may consider immaterial evidence), cert. denied, 352 U.S. 981 (1957).

13. See United States v. Scully, 225 F.2d 113, 116 (2d Cir.), cert. denied, 350 U.S. 897 (1955); In re Black, 47 F.2d 542, 543 (2d Cir. 1931). A witness may leave the room to consult with his attorney. See United States v. Capaldo, 402 F.2d 821, 824 (2d Cir. 1968), cert. denied, 394 U.S. 989 (1969).

14. See Comment, Grand Jury Secrecy: Should Witnesses Have Access to Their Grand Jury Testimony as a Matter of Right?, 20 U.C.L.A. L. REV. 804 (1973).

15. See, e.g., Douglas Oil Co. v. Petrol Stops Northwest, 441 U.S. 211, 218-19 (1979); United States v. Proctor \& Gamble Co., 356 U.S. 677, 681-82 (1958); see also United States v. Rose, 215 F.2d 617, 628-29 (3d Cir. 1954).

16. In re Disclosure of Testimony, 580 F.2d 281, 287 (8th Cir. 1978); In re Grand Jury, 583 F.2d 128, 130-31 (5th Cir. 1978); see also United States v. Socony-Vacuum Oil Co., 310 U.S. 150, 234 (1940) ("[A]fter the grand jury's functions are ended, disclosure is wholly proper where the ends of justice require it.").

17. Douglas Oil Co. v. Petrol Stops Northwest, 441 U.S. 211, 222-23 (1979); see also U.S. Indus., Inc. v. United States Dist. Court, 345 F.2d 18, 21-22 (9th Cir.) ("if the reasons for maintaining secrecy ... apply to only an insignificant degree," party seeking disclosure need not demonstrate a large compelling need), cert. denied, 382 U.S. 814 (1965); 1 C. WRIGHT, FEDERAL PRACTICE \& PROGEDURE § 106, at 173 (1969). The Supreme Court allows disclosure of grand jury material to 
But since two reasons for secrecy-protection of the innocent accused and prevention of retaliation against witnesses-usually retain their vitality even after the grand jury investigation has ended, ${ }^{18}$ the secrecy requirement is merely relaxed, and not eliminated, when the investigation ends. In addition, the Supreme Court has cautioned courts to consider not only the immediate effects of disclosure upon a particular grand jury but also the possible effect upon the functioning of future grand juries. ${ }^{19}$ Each disclosure potentially deters those who would come forward and aid future grand juries, because persons called to testify will consider the likelihood that their testimony one day may be disclosed to outside parties.

private litigants upon a three-fold showing: that the material was needed to avoid a possible injustice in another proceeding, that the need for disclosure was greater than the need for continued secrecy, and that the disclosure request was structured to cover only the material so needed. Douglas Oil, 441 U.S. at 222. Such a showing typically is made when private litigants seek to use a grand jury transcript at trial to refresh a witness's recollection or to test his credibility. Id. at 222 n.12. Disclosure is then justified "to avoid misleading the trier of fact." Id. Such disclosure is limited to "those portions of a particular witness' testimony that bear upon some aspect of direct testimony at trial." Id.

The Supreme Court has never addressed the issue of whether a government agency seeking disclosure must make the same showing as is required of private litigants. Many lower courts apply a reduced standard when a government agency seeks grand jury materials. The Fourth and Fifth Gircuits have adopted the most lenient standard of need for agency requests, requiring only that the grand jury materials sought are "rationally related" to the civil matters the government is investigating. In re Grand Jury Subpoenas, 581 F.2d 1103, 1110 (4th Cir. 1978), cert. denied, 440 U.S. 971 (1979); In re Grand Jury, 583 F.2d 128, 131 (5th Cir. 1978); In re December 1974 Term Grand Jury Investigation, 449 F. Supp. 743, 751 (D. Md. 1978).

A few courts, however, have suggested that the government must demonstrate the same degree of need as private litigants and have denied disclosure requests for failure to meet this standard. Sells, Inc. v. United States, 642 F.2d 1184, 1192 (9th Cir. 1981) ("The showing of a rational relationship between the [grand jury] materials and the civil proceeding may explain the Government's desire for disclosure, but it does not help determine the degree of necessity."), cert. granted sub nom. United States v. Sells Eng'g, Inc., 102 S. Ct. 2034 (1982) (No. 81-1032); In re United States Order Pursuant to Provisions of Rule 6(e), 505 F. Supp. 25, 27 (W.D. Pa. 1980) (relevance is "merely a minimal first step" toward showing particularized need). Given the public interest inherent in an agency's disclosure request, this approach is questionable. See infra note 90.

In a special class of cases, some courts have dropped the need requirement altogether. Under 15 U.S.C. $\$ 15($ () (1976), a state Attorney General may request investigative files of the Justice Department for use in the state's antitrust suit. The Fourth and Ninth Gircuits have recently held that grand jury testimony is included as part of the investigative files and that a state does not have to show need to obtain grand jury material. United States v. Colonial Chevrolet Corp., 629 F.2d 943 (4th Cir. 1980), cert. denied, 450 U.S. 943 (1981); United States v. B.F. Goodrich Co., 619 F.2d 798 (9th Cir. 1980). Contra In re Grand Jury Investigation of Cuisinarts, Inc., 665 F.2d 24 (2d Cir. 1981); In re Illinois Petition, 659 F.2d 800 (7th Cir. 1981), cert. granted sub nom. Illinois v. Abbott \& Assocs., Inc., 102 S. Ct. 1708 (1982) (No. 81-1114).

18. See, e.g., Illinois v. Sarbaugh, 552 F.2d 768, 774-75 (7th Cir.), cert. denied, 434 U.S. 889 (1977); U. S. Indus., Inc. v. United States Dist. Court, 345 F.2d 18, 22 (9th Cir.), cert. denied, 382 U.S. 814 (1965); In re Cement-Concrete Block, 381 F. Supp. 1108, 1110 (N.D. Ill. 1974). But cf. In re Grand Jury, 583 F.2d 128, 130-31 (5th Cir. 1978) (less likely that innocent person will suffer injury to reputation after investigation is completed); Government Brief in Support of Petition for Rehearing at 12, Sells, Inc. v. United States, 642 F.2d 1184 (9th Gir. 1981) ("[P]rotection of innocent accused" rationale loses vitality with respect to corporation when corporate officers have been indicted and plead guilty.), cert. granted sub nom. United States v. Sells Eng'g, Inc., 102 S. Ct. 2034 (1982) (No. 81-1032).

19. Douglas Oil Co. v. Petrol Stops Northwest, 441 U.S. 211, 222 (1979). 


\section{B. The Argument for Agency Access}

Federal statutes generally grant administrative agencies considerable power to compel the production of documents and the testimony of witnesses when the disclosure of such information is necessary to carry out the rulemaking, policymaking, and adjudicatory functions that are delegated to agencies by the legislature. ${ }^{20}$ Grand juries often subpoena documents and testimony that would facilitate administrative agency investigations. In addition, grand juries frequently receive reports, prepared by administrative agency personnel, that analyze and evaluate testimonial and documentary evidence. ${ }^{21}$ Such reports could also be valuable in subsequent agency proceedings. Often administrative agencies request these materials to avoid the time and expense involved in duplicating a completed investigation. ${ }^{22}$ When agencies are forced to begin every investiga-

20. Detailed provisions, however, may vary from agency to agency. Compare 15 U.S.C. $\S 46$ (1976 \& Supp. V 1981) (FTC investigatory powers limited in certain areas) with I.R.C. $\$ 7602$ (West 1982) (IRS given wide-ranging summons power). For a comprehensive survey of the investigative authority of administrative agencies, see K. DAVIS, ADMINISTRATIVE LAW TREATISE $\S 4$ (2d ed. 1978).

The investigatory powers of administrative agencies are more limited than those of the grand jury. See In re Grand Jury Subpoenas, 581 F.2d 1103, 1107-08 (4th Cir. 1978) (grand jury obtained documents after IRS subpoena was quashed), cert. denied, 440 U.S. 971 (1979); Note, Administrative Agency Access to Grand Jury Materials, 75 ColuM. L. REV. 162, 175-82 (1975) (comparing administrative agency powers with grand jury powers and arguing increased agency access to grand jury materials may result in "undesirable expansion of agency power"). But cf. United States v. Morton Salt Co., 338 U.S. 632, 642-43 (1950) (administrative agency's investigative powers "analogous" to those of a grand jury).

21. FED. R. CRIM. P. 6(e)(3)(A)(ii) (empowering government attorneys to use agency personnel in grand jury investigations). Agency personnel can gather and present to prosecutors information relating to criminal behavior. S. REP. No. 354, 95th Cong., 1st Sess. 6-7, reprinted in 1977 U.S. CODE CONG. \& AD. NEWS 527, 530. More important, the prosecutors often utilize the expertise of agency personnel in evaluating and analyzing evidence before presenting it to grand juries. Id.

Even before rule $6(\mathrm{e})(3)(\mathrm{a})$ (ii) was enacted in 1977, courts recognized the need for agency assistance in grand jury investigations. See, e.g., Robert Hawthorne, Inc. v. Director of Internal Revenue, 406 F. Supp. 1098 (E.D. Pa. 1976) (allowing administrative agency personnel to assist grand jury investigation by analyzing and evaluating documents because of their resources and expertise); In re William H. Pflaumer \& Sons, Inc., 53 F.R.D. 464 (E.D. Pa. 1971) (same). But cf. United States v. Tager, 638 F.2d 167, 169-70 (10th Cir. 1980) (disclosure to private insurance investigator improper).

22. This problem is particularly acute for the IRS, which contributes significant resources to assist attorneys for the government in grand jury litigation, particularly tax investigations involving narcotics trafficking and other racketeering activities. Statement of Roscoe L. Egger, Jr., Commissioner of Internal Revenue, before the Advisory Committee on Criminal Rules, Judicial Conference of the United States (Feb. 10, 1982) (on file with Yale Law Journal). At the end of 1981, the IRS was assisting in 1,148 grand jury investigations of targets suspected of underpayment of taxes or illegally obtaining income. Id.

Criminal tax investigations typically are complex and often involve thousands of evidentiary items which, only after thorough analysis, reveal a tax fraud and underlying tax liability. Statement of Robert P. Ruwe, Director, Criminal Tax Division, and Chief Counsel, Internal Revenue Service, before the Advisory Committee on Criminal Rules, Judicial Conference of the United States (Feb. 10, 1982) (on file with Yale Law Journal) [hereinafter cited as Ruwe Statement].

A grand jury investigating the General Motors Corporation, for example, subpoenaed between 200,000 and 300,000 pages of material which were "stamped, numbered, and analyzed by attorneys for the government together with IRS agents assisting them." In re April Grand Jury Proceedings, 506 F. Supp. 1174, 1176 (E.D. Mich. 1981). In another tax investigation, the grand jury subpoenaed 
tion de novo, they not only waste resources but also risk statute of limitations problems. ${ }^{23}$ Under the secrecy restrictions of Rule 6(e), however, such materials are usually unavailable to the agencies. ${ }^{24}$

Effective civil law enforcement and efficient administration require that the government make full use of available evidence. During their investigations, grand juries often receive evidence of significant civil liabilities. Public policy argues strongly in favor of lifting the veil of secrecy that covers such evidence.

\section{The Judicial Proceeding Provision: An Inadequate Solution}

Courts have relied heavily upon the "judicial proceeding" provision of Rule 6(e) to resolve the tension between the need for agency access to information and the need for grand jury secrecy. This provision, however, was not drafted with administrative agencies in mind. Thus, its application to agency disclosure requests has yielded inconsistent and unsound results.

\section{A. Legislative History}

An analysis of the legislative history of Rule 6(e) reveals that the Advisory Committee that drafted it did not consider the impact that the Rule would have on administrative agencies. This omission is understandable, in part, because administrative law was relatively undeveloped when the

over 12,000 checks and 5,000 petty cash vouchers which were "inspected and traced" through corporate records by IRS personnel. Robert Hawthorne, Inc. v. Director of Internal Revenue, 406 F. Supp. 1098, 1113 (E.D. Pa. 1976).

Denying disclosure requests by the IRS may result in complete reinvestigation and analysis by different agents who have not previously been involved in the grand jury investigation. The result is the loss of time and government resources, if the analysis can be duplicated, or, if the analysis cannot be duplicated, the loss of revenue to the government, which may total millions of dollars. See Petition of the United States for Disclosure of Grand Jury Matters (Miller Brewing Co.), 518 F. Supp. 163, 168 (E.D. Wis. 1981) (government seeking disclosure because "some of the material may no longer exist"), aff'd in part, rev'd in part, 687 F.2d 1079 (7th Cir. 1982).

In addition to wasting the resources of administrative agencies, duplicating grand jury investigations may unduly burden third parties. See id.; see also In re Grand Jury, 583 F.2d 128, 131 (5th Cir. 1978) (disclosure obviates "needless duplication of effort" by third parties).

23. In some cases, the loss of time might preclude civil law enforcement entirely. For instance, in Sells, Inc. v. United States, 642 F.2d 1184 (9th Cir. 1981), cert. granted sub nom. United States v. Sells Eng'g, Inc., 102 S. Ct. 2034 (1982) (No. 81-1032), the government sought grand jury material in connection with a civil action under the False Claims Act, 31 U.S.C. \$§ 231-235 (1976 \& Supp. V 1981), and a common law action to recover overcharges the defendant had obtained from the Navy. The government's need to review the grand jury material was based partly on the possible running of statutes of limitation. Government Brief in Support of Petition for Rehearing at 2.

24. See In re Special Feb., 1975 Grand Jury, 662 F.2d 1232 (7th Gir. 1981) (analysis prepared by agent covered by rule of secrecy because it incorporates grand jury testimony), cert. granted sub nom. United States v. Baggot, 102 S. Ct. 2955 (1982) (No. 81-1938); Interviews, supra note 2; Ruwe Statement, supra note 22. But see In re Grand Jury Proceedings, 505 F. Supp. 978, 981-82 (D. Me. 1981) (FBI reports incorporating documents not covered by rule 6(e)). 
Federal Rules of Criminal Procedure were enacted in $1946 .{ }^{25}$ Comments by its members indicate that the Advisory Committee was concerned primarily with regulating grand jury disclosure to defendants who wanted to challenge their indictments. ${ }^{26}$ Indeed, the Advisory Committee's Note accompanying Rule $6(\mathrm{e})$ cites only cases dealing with disclosure to criminal defendants. ${ }^{27}$

The Committee was also silent on the intended function of the "judicial proceeding" provision. The most likely source of this provision is Section 126 of the American Law Institute's Code of Criminal Procedure (ALI Code). ${ }^{28}$ Section 126 was a model oath for grand jurors, which permitted disclosure only "in the due course of judicial proceedings." 29 Perhaps the drafters of Rule 6(e) appropriated the phrase, intending to adopt the ALI's codification of the common law.

25. Although agencies such as the Federal Communications Commission and FTC had been controlling the anticompetitive conduct of monopolies and other powerful corporations since the turn of the century, and a great proliferation of administrative agencies occurred during the New Deal, see K. DAvIS, supra note $20, \S 1$, cases discussing agency access to grand jury materials appeared infrequently prior to the 1970 's. The Advisory Committee received only one comment during the drafting period concerning rule 6(e)'s impact on administrative agencies, that of Richard S. Rubin, Special Counsel to the Securities and Exchange Commission, who stated:

I would like to urge the Committee to change the present Rule 6 (e) so as to permit disclosure of such matters in connection with federal administrative proceedings. In the same connection I think it should be noted that the phrase "judicial proceeding" might be construed to include state court proceedings, and I have some question as to whether that would be desirable.

4 United States Supreme Court Advisory Comm. on Rules of Criminal Procedure, Comments, Recommendations, and Suggestions on the Federal Rules of Criminal Procedure 12 (1944) (unpublished manuscript, available in Yale Law School Library).

26. See NEW YORK UNIV. SCHOOL OF LAW, FEDERAL RULES OF CRIMINAL PROCEDURE WITH NOTES AND INSTITUTE PROCEEDINGS 154 (1946) (comments of Judge Medalie) (new rule would "directly and expeditiously" enable criminal defendants to challenge their indictments); Dession, New Federal Rules of Criminal Procedure: II, 56 YALE L.J. 197, 203 (1947) (provision for disclosure "designed to save time and facilitate proof where a motion to dismiss an indictment is made in good faith"). Judge Medalie and Professor Dession were members of the Supreme Court Advisory Committee that drafted the Federal Rules.

27. The original rule $6(\mathrm{C})$ stated in pertinent part:

[A] juror, attorney, interpreter or stenographer may disclose matters occurring before the grand jury only when so directed by the court preliminarily to or in connection with a judicial proceeding or when permitted by the court at the request of the defendant upon a showing that grounds may exist for a motion to dismiss the indictment because of matters occurring before the grand jury.

Fed. R. Crim. P. 6(e) (1946).

28. The ALI Code, published in 1931, compiled and codified the common law of criminal procedure of various states. The Advisory Committee relied on the ALI Code as a legislative model. In fact, specific citations to the ALI Code appear in the Notes on rule 6(e) in the preliminary drafts of the Federal Rules. See UNITED STATES SUPREME COURT ADVISORY COMM. ON RULES OF CRIMINAL PROcedure, Federal Rules of Criminal Procedure 25 (1943) (preliminary draft).

29. Section 126 of the ALI Code, entitled "Oath of grand jurors," states in pertinent part: "You will keep your own counsel and that of your fellows and of the State [Commonwealth or People], and will not, except when required or permitted in the due course of judicial proceedings, disclose the testimony of any witness examined before you . . . ." AMERICAN LAW INSTITUTE, CODE OF CRIMINAL PROCEDURE $\S 126$ (Official Draft 1930) (emphasis added). 
Yet the ALI Code itself, in section $145,{ }^{30}$ preserved the traditional discretion of the courts to disclose grand jury material "in the furtherance of justice," even in the absence of judicial proceedings. ${ }^{32}$ Thus, section 145 was a declaration of substantive judicial power much broader than the mere oath for grand jurors in section 126. The two sections should properly be read together as a codification of the "traditional practice" of secrecy. ${ }^{32}$ By appropriating only the wording of section 126, the drafters of Rule 6(e), inadvertently perhaps, limited the traditional discretion of the courts with regard to grand jury disclosure. ${ }^{\text {ss }}$

Another possible explanation for the "judicial proceeding" provision is that the drafters intended it to limit the issuance of grand jury reports. At common law, grand juries would investigate conditions that affected the

30. Section 145 of the ALI Code, entitled "Testimony not to be disclosed-exception," states: No grand juror, prosecuting attorney, stenographer or interpreter shall disclose the testimony of a witness examined before the grand jury or other evidence received by it except when required by a court to disclose the testimony of a witness examined before the grand jury for the purpose of ascertaining whether it is consistent with that of the witness given before the court, or to disclose the testimony given before the grand jury by any person upon a charge against such person for perjury in giving his testimony or upon trial therefor, or when permitted by the court in the furtherance of justice.

AMERICAN LAW INSTITUTE, supra note 29 , at $\S 145$ (emphasis added).

31. Although most cases that allowed disclosure pursuant to the "traditional practice" did involve pending judicial proceedings, disclosure did not turn on the existence of such proceedings. See Annot., 127 A.L.R. 272 (1940). Indeed, two cases that relied upon the "traditional practice" permitted disclosure of grand jury material in administrative settings. See People ex rel. Hirschberg v. Board of Supervisors, 251 N.Y. 156, 167 N.E. 204 (1929) (permitting grand jurors, before whom county district attorncy had presented case, to testify before county administrative board, which was considering whether citizen who had petitioned governor for removal of district attorney should be reimbursed by county for related expenses); In re Grand Jury Proceedings, 4 F. Supp. 283, 285 (E.D. Pa. 1933) (releasing materials pursuant to hearing on revocation of brewing company's permit, and indicating that whether materials were sought by a court or an agency was immaterial). In the latter case, an "interest of justice" test was applied. Id. at 284.

32. The "traditional practice" of secrecy has been said to permit disclosure "in the furtherance of justice." See Goodman v. United States, 108 F.2d 516, 521 (9th Cir. 1939); see also In re United States v. Socony-Vacuum Oil Co., 310 U.S. 150, 234 (1940) (permitting disclosure "where the ends of justice require it"); In re Grand Jury Proceedings, 4 F. Supp. 283, 284 (E.D. Pa. 1933) (permitting disclosure "whenever the interest of justice requires").

Even in the absence of Section 145, a construction of the ALI Code (and rule 6(e)) that preserves the "traditional practice" would be in keeping with numerous early twentieth century cases that broadly construed narrow statutory exceptions to grand jury secrecy. Many such statutes, for example, limited grand jury disclosure to two instances: 1) impeachment of a witness at trial, and 2) evidence in the perjury trial of a grand jury witness. Courts, however, generally held that these statutes were only partial declarations of the common law, not intended to interfere with "traditional practice," which allowed disclosure "in the furtherance of justice." See, e.g., Hinshaw v. State, 147 Ind. 334, 375-77, 47 N.E. 157, 170 (1897) (permitting disclosure in criminal trial); United States v. McDonald, 4 Alaska 630, 638-42 (1913) (permitting disclosure in bail hearing); People ex rel. Hirschberg v. Board of Supervisors, 251 N.Y. 156, 171, 167 N.E. 204, 210-11 (1929) (permitting disclosure in administrative hearing).

A few federal courts have used a similar approach in construing rule 6(e). See In re Report \& Recommendation of June 5, 1972 Grand Jury, 370 F. Supp. 1219 (D.D.C.), mandamus denied sub nom. Haldeman v. Sirica, 501 F.2d 714 (D.C. Cir. 1974); In re Bullock, 103 F. Supp. 639 (D.D.C. 1952); infra p. 1631.

33. But see Note, Federal Agency Access to Grand Jury Transcripts Under Rule 6(e), 80 Mich. L. REV. 1665,1674 (1982) ("preliminarily to" phrase adopted to relax secrecy requirement). 
morals, health, sanitation, or general welfare of their communities and issue nonindicting, although sometimes critical, reports. ${ }^{34} \mathrm{~A}$ substantial body of caselaw supported this practice as long as the reports focused on general areas of public concern. ${ }^{35}$ When reports discussed individuals, however, courts expressed concern with providing the targets of the reports forums in which to rebut the charges levied against them. ${ }^{36}$

Perhaps, then, the "judicial proceeding" provision was placed in Rule 6(e) to insure that grand jury material would not be disclosed unless any person hurt by the disclosure would have a forum in which to defend himself. ${ }^{37}$ But courts have not construed the "judicial proceeding" provision as a limitation on their authority to release grand jury reports. Instead, they have adopted a broader approach reminiscent of the "traditional practice" of secrecy that permitted disclosure "in the furtherance of justice" and have released reports even in the absence of judicial proceedings. ${ }^{38}$ On the other hand, courts continue to deny most disclosure requests by administrative agencies even though administrative hearings can provide adversarial forums to individuals where they may defend

34. The purpose of these reports was to arouse public attention and legislative indignation. Sec In re Grand Jury Proceedings, 479 F.2d 458, 460 n.2 (5th Cir. 1973) (collecting cases).

35. See United States v. Cox, 342 F.2d 167, 186-90 (5th Cir.) (Wisdom, J., concurring) (discussing history of grand jury reports and collecting cases), cert. denied, 381 U.S. 935 (1965). But see In re Report \& Recommendation of June 5, 1972 Grand Jury, 370 F. Supp. 1219, 1222-26 (D.D.C.) (noting that authority of federal grand juries to issue reports remains unsettled), mandamus denied sub nom. Haldeman v. Sirica, 501 F.2d 714 (D.C. Cir. 1974).

36. See Judge Weinfeld's oft-cited opinion in United Elec. Radio \& Machine Workers, 111 F. Supp. 858, 869 (S.D.N.Y. 1953) (recognizing that "reports of a general nature touching on conditions in the community . . . may serve a valuable function and may not be amenable to challenge," but disapproving of accusatory pronouncements that publicly condemn and yet bar their victim from a judicial forum in which to clear his name); see also People v. McCabe, 148 Misc. 330, 333, 266 N.Y.S. 363, 367 (Sup. Ct. 1933) ("A [report] is a foul blow. It wins the importance of a judicial document; yet it lacks its principal attributes-the right to answer and to appeal. It accuses, but furnishes no forum for denial."); cf. Doe v. Rosenberry, 255 F.2d 118, 120 (2nd Cir. 1958) (citing United Elec. Workers in distinguishing between disclosure in an adversary context and grand jury report).

37. Cf. Note, supra note 20 , at 174-75 (noting potential for circumvention of secrecy requirement through grand jury reports). Although some courts have suggested a connection between grand jury reports and rule 6(e), see, e.g., Doe v. Rosenberry, 255 F.2d 118, 120 (2d Cir. 1958); In re Report \& Recommendation of June 5, 1972 Grand Jury, 370 F. Supp. 1219 (D.D.C.), mandamus denied sub nom. Haldeman v. Sirica, 501 F.2d 714 (D.C. Cir. 1974); United Elec. Radio \& Machine Workers, 111 F. Supp. 858, 865-66 (S.D.N.Y. 1953), neither courts nor commentators have suggested that curbing grand jury reports was the raison d'être for the "judicial proceeding" provision.

38. In re Grand Jury January, 1969, 315 F. Supp. 662 (D. Md. 1970), for example, involved a report that was publicly released in summarized form after the court had noted the rampant speculation about the report and had weighed "the public interest in disclosure" against "the private prejudice to the persons involved, none of whom are charged with any crime in the proposed indictment." Id. at 679. The court further observed that, if materials are released, "[t]he Court should regulate the amount of disclosure, to be sure that it is no greater than is required by the public 'interest in knowing' when weighed against the rights of the persons mentioned in the presentment." Id. at 678; accord In re Grand Jury Proceedings, 479 F.2d 458, 460 \& n.2 (5th Cir. 1973); see also infra p. 1631 (discussing "Watergate" disclosure case). 
themselves. ${ }^{30}$

In sum, the source and purpose of the "judicial proceeding" provision is unclear. There is no evidence, however, to suggest that the provision was intended to resolve the tension between administrative agencies' need for information and grand juries' need for secrecy.

\section{B. Judicial Application}

The "judicial proceeding" provision of Rule 6(e) has two conceptually distinct components: the "preliminarily to or in connection with" component and the "judicial proceeding" component. ${ }^{10}$ In evaluating requests for disclosure, most courts have attempted to apply the literal requirements of the judicial proceeding provision. In some cases, however, this approach has been ignored and a public interest standard has been used instead.

\section{Literal Approach}

Doe v. Rosenberry ${ }^{11}$ was the first case to distinguish clearly the two components of the judicial proceeding provision. ${ }^{\mathbf{2}}$ The issue in the case was whether grand jury minutes should be made available to the Grievance Committee of the New York City Bar Association. ${ }^{43}$ Judge Learned

\section{See infra note 48 .}

40. The "preliminarily to or in connection with" phrase itself contains two components. The word "preliminarily" is applicable to future proceedings; the words "in connection with" apply to current judicial proceedings. Courts, however, have not been concerned with this subtlety.

41. 255 F.2d 118 (2d Cir. 1958).

42. Two cases decided in 1952 involving disclosure requests from administrative bodies illustrate early disagreement over the meaning of the "judicial proceeding" provision. In United States v. Crolich, 101 F. Supp. 782 (S.D. Ala. 1952), the court declared that the "judicial proceeding" phrase contemplated "a proceeding pending in a District Court which would necessitate the disclosure of matters occurring before a grand jury empaneled by that court." Id. at 784. Thus the Crolich court refused to release grand jury testimony concerning corrupt electoral practices to a municipal board that appointed election officials. This narrow construction, were it consistently followed, would effectively bar disclosure to any administrative agency.

In In re Bullock, 103 F. Supp. 639 (D.D.C. 1952), by contrast, the court broadly construed the "judicial proceeding" provision as a codification of the traditional practice of secrecy. The court declared, "by way of interpretation [of the rule], the Federal Courts have extended their jurisdiction so that they may remove the seal of privacy from Grand Jury proceedings when in the Court's discretion the furtherance of justice requires it." Id. at 641. Thus, in Bullock, a police disciplinary board succeeded in having grand jury testimony of a department inspector, suspected of misconduct, made available to its outside advisory committee. Id. at 643.

Crolich's narrow construction has been followed by only one district court. See United States v. Downey, 195 F. Supp. 581, 584 (S.D. Ill. 1961). The Downey interpretation has been overruled, sub silentio, by the Seventh Circuit. See Jachimowski v. Conlisk, 490 F.2d 894 (7th Cir. 1973) (permitting disclosure of policemen's grand jury testimony to superintendent of police).

Bullock's liberal intepretation of rule 6(e) generally has been confined to similar fact patterns. See Conlisk, 490 F.2d at 897 . Disclosure in such instances has been permitted because of the strong public interest in maintaining the "integrity and credibility" of the police department. Id. at 898. This policy argument, while a factor in the Bullock opinion, was not dispositive in that case.

43. After investigating charges of corruption in government, the grand jury did not indict the 
Hand affirmed the disclosure order of the lower court because (i) the Committee investigation was preliminary to charges being brought before the bar's disciplinary body, the Appellate Division of the New York Supreme Court, ${ }^{44}$ and (ii) the Appellate Division proceeding was a "judicial proceeding." 45

Judge Hand tailored a definition of "judicial proceeding" to fit the facts of the case:

[P]rima facie, the term "judicial proceeding" includes any proceeding determinable by a court, having for its object the compliance of any person, subject to judicial control, with standards imposed upon his conduct in the public interest, even though such compliance is enforced without the procedure applicable to the punishment of crime. $^{48}$

This definition has dominated judicial discussions of the "judicial proceeding" provision. Courts regularly deny disclosure requests by administrative agencies because administrative hearings are not "determinable by a court." ${ }^{\text {"47 }}$ Strict adherence to Judge Hand's definition seems questionable, however, as many administrative hearings are quasi-judicial, ${ }^{48}$ and

target of the investigation, a member of the New York City Bar. Rosenberry, 255 F.2d at 119. The jury, however, unanimously voted that the activities of the attorney be referred to the Grievance Committee. Id.

44. The question of whether the Grievance Committee's investigation was preliminary to the disciplinary proceeding, according to Judge Hand, "admits of no doubt." Id. at 120 . Hand found both statutory and judicial support for the proposition that the settled practice of referring complaints against attorneys to a bar grievance committee satisfied the "preliminarily to" requirement. Id. at 120 . Subsequent cases have relied on this aspect of Rosenberry in permitting disclosure to bar and police disciplinary bodies. See infra note 50 .

45. 255 F.2d at 120.

46. Id.

47. In re United States v. Bates, 627 F.2d 349, 351 (D.C. Cir. 1980) (adjudicatory hearing before Federal Maritime Commission regarding possible violations of Shipping Act not a judicial proceeding); In re J. Ray McDermott \& Co., 622 F.2d 166, 170 (5th Cir. 1980) (hearings before Federal Energy Regulatory Commission (FERC) regarding utility rates "are not quasi-judicial but, rather, are purely administrative"); In re Grand Jury Matter, 495 F. Supp. 127, 132-33 (E.D. Pa. 1980) (adjudicatory hearing before Department of Labor regarding citation by Mine Safety and Health Administration not a judicial proceeding).

48. Butz v. Economou, 438 U.S. 478 (1978), in holding that absolute immunity heretofore enjoyed by federal and state judges should be extended to administrative law judges, provided a pithy comparison of the judicial and the administrative process:

[F]ederal administrative law requires that agency adjudication contain many of the same safeguards as are available in the judicial process. The proceedings are adversary in nature. See 5 U.S.C. § 555(b) (1976 ed.). They are conducted before a trier of fact insulated from political influence. See $\S 554$ (d). A party is entitled to present his case by oral or documentary evidence, $\S 556(\mathrm{~d})$, and the transcript of testimony and exhibits together with the pleadings constitute the exclusive record for decision. $\S 556(\mathrm{e})$. The parties are entitled to know the findings and conclusions on all of the issues of fact, law, or discretion presented on the record. $\S 557(\mathrm{c})$.

There can be little doubt that the role of the modern federal hearing examiner or adminisId. at 513 .

trative law judge within this framework is "functionally comparable" to that of a judge. 
Judge Hand himself indicated that a broader definition of judicial proceeding might be appropriate. ${ }^{49}$

In contrast to the widespread application of Judge Hand's “judicial proceeding" definition, his lenient approach in Rosenberry to the "preliminarily to" component has been followed only in cases involving bar grievance and police disciplinary hearings. ${ }^{50}$ Another early case, In re Grand Jury Proceedings, ${ }^{\text {,1 }}$ provides the touchstone for analyzing the "preliminarily to" requirement in other contexts. This case involved a disclosure request from the Federal Trade Commission (FTC), which was investigating possible violations of its cease and desist orders. If the FTC found such violations, it was required by statute to notify the Attorney General, who in turn was required to institute an enforcement proceeding in federal court. ${ }^{82}$ Yet the Third Circuit denied the FTC's request, stating that "[t]here is no judicial proceeding now pending and it is possible that none may result from the investigation."

Subsequent decisions have continued to require varying degrees of certainty that judicial proceedings will follow the administrative investigation before grand jury material is disclosed. ${ }^{54}$ For instance, the mere possibility of judicial review of an administrative decision has not satisfied this certainty requirement. ${ }^{55}$ Thus, the "preliminarily to" component of the "judicial proceeding" provision is inconsistently applied: grand jury material

49. After defining a "judicial proceeding," Judge Hand stated, "An interpretation that should not go at least so far, would not only be in the teeth of the language employed, but would defeat any rational purpose that can be imputed to the Rule." Rosenberry, 255 F.2d at 120 (emphasis added). Hand's cautious language may be explained by the fact that this was the first federal appellate consideration of an administrative agency disclosure request under rule $6(\mathrm{e})$.

50. See, e.g., United States v. Sobotka, 623 F.2d 764, 766 (2d Cir. 1980) (citing Rosenberry for proposition that bar grievance committee meets "judicial proceeding" requirement); Jachimowski v. Conlisk, 490 F.2d 894, 896-97 (7th Cir. 1973) (disclosure to police board of inquiry); United States v. Salanitro, 437 F. Supp. 240, 243-44 (D. Neb. 1977) (disclosure to bar disciplinary body, judicial disciplinary body, and local prosecutor), aff'd sub nom. In re Disclosure of Testimony, 480 F.2d 281 (8th Cir. 1978). These bodies also benefit from a lowered "particularized need" standard. See supra note 17; infra note 90 .

51. 309 F.2d 440 (3rd Cir. 1962).

52. 15 U.S.C. $\S 56$ (1976).

53. 309 F.2d at 444.

54. See, e.g., In re J. Ray McDermott \& Co., 622 F.2d 166, 171 (5th Cir. 1980) (disclosure denied because "possibility of [FERC] enforcement proceeding is remote"); In re Disclosure of Testimony, 580 F.2d 281, 286 (8th Cir. 1978) (administrative proceeding must be "designed to culminate" in judicial proceeding); Patrick v. United States, 524 F.2d 1109, 1117 (7th Cir. 1975) (judicial proceeding must be "reasonably anticipate[d]"); Jachimowski v. Conlisk, 490 F.2d 894, 897 (7th Cir. 1973) (disclosure proper where statutory scheme "plainly contemplates" judicial review of administrative decision); In re Grand Jury Matter, 495 F. Supp. 127, 132 (E.D. Pa. 1980) (must be "clear pathway" from administrative process to judicial process); In re December 1974 Term Grand Jury Investigation, 449 F. Supp. 743, 751 (D. Md. 1978) (administrative investigation must have "some rational connection with a specific existing or contemplated judicial proceeding").

55. In re Grand Jury Matter, 495 F. Supp. 127, 132-33 (E.D. Pa. 1980) (denying disclosure because judicial review of Department of Labor's decision limited to "substantial evidence" standard); United States v. Young, 494 F. Supp. 57, 60 (E.D. Tex. 1980) (denying disclosure because judicial review of state board of medical examiners' decision was "a remote potentiality"). 
is regularly disclosed to agencies such as bar and police disciplinary bodies, ${ }^{56}$ despite the often tenuous link between these investigations and ultimate judicial resolution, ${ }^{57}$ but is withheld from most other agencies, regardless of the likelihood of judicial review of their decisions. ${ }^{58}$

The application of the "preliminarily to" component of the "judicial proceeding" provision is inconsistent even within a single agency, the Internal Revenue Service (IRS). The IRS sometimes requests disclosure of grand jury material to facilitate its conduct of a civil tax audit. Several courts have denied these requests on the ground that they are not preliminary to a judicial proceeding. ${ }^{58}$ In In re Special February, 1975 Grand Jury (Baggot) ${ }^{60}{ }^{60}$ for example, the Seventh Circuit denied an IRS request for grand jury material pertaining to the civil tax liability of James Baggot, who had pled guilty to fraudulent commodity trading. It ruled that a tax audit was "too embryonic, speculative, and uncertain to firmly say

56. See, e.g., Jachimowski v. Conlisk, 490 F.2d 894 (7th Cir. 1973) (disclosure to police disciplinary body); United States v. Salanitro, 437 F. Supp. 240 (D. Neb. 1977) (disclosure to four separate administrative bodies charged with investigating misconduct of public officials), affd sub nom. In re Disclosure of Testimony Before Grand Jury, 580 F.2d 281 (8th Cir. 1978). But see United States v. Sobotka, 623 F.2d 764 (2nd Cir. 1980) (denying disclosure to bar association committee because of failure to show particularized need).

57. For example, a bar disciplinary committee may decide not to bring a court action. Or, where a disciplinary committee takes disciplinary action without resorting to court, a "judicial proceeding" would not take place absent an appeal. See Jachimowski v. Conlisk, 490 F.2d 894, 896 (7th Cir. 1973) (stating that policeman would have right to raise issue of disclosure on appeal). A target of such action may forego his right to appeal; cf. infra pp. 1629-30 (discussing taxpayer's right to appeal in IRS cases and effect on disclosure).

58. Courts and commentators have noted that the distinction is illogical. See In re Judge Elmo B. Hunter's Special Grand Jury, 667 F.2d 724, 728 (8th Cir. 1981) ("no substantial difference" between IRS request and those of bar committee and police disciplinary bodies); Note, supra note 20, at 172 ("Few sensible distinctions" can be drawn between police and bar disciplinary body requests and other administrative agency requests.); $c f$. In re Report \& Recommendation of June 5, 1972 Grand Jury, 370 F. Supp. 1219, 1230 (D.D.C. 1973) ("[I]t seems incredible that grand jury matters should lawfully be available to disbarment committees and police disciplinary investigations and yet be unavailable to the House of Representatives in a proceeding of so great import as an impeachment investigation."), mandamus denied sub nom. Haldeman v. Sirica, 501 F.2d 714 (D.C. Cir. 1974). But cf. Note, supra note 33, at 1669-72 (attempting to organize rule 6(e) cases along two lines: likelihood of judicial proceedings as matter of fact and as matter of law). The arbitrariness of the results under the "preliminarily to" requirement is well-illustrated in a recent Third Circuit case, In re Grand Jury Matter, 682 F.2d 61 (3rd Cir. 1982), which involved the disclosure request of a state district attorney. Faced with two inconsistent and seemingly irreconcilable lines of cases-the bar and police disciplinary body cases (employing a lenient "preliminarily to" standard) and the other agency cases (employing a stringent standard)-the court likened the district attorney's request to the former, stating simply: "The prosecutorial discretion to refrain ultimately from making a charge is not the type of contingency which renders the likelihood of future judicial proceedings too embryonic to provide the predicate for a disclosure . . . Id. at 65. This pronouncement is nothing more than an jpse dixit: the potential prosecution could just as easily have been termed too speculative, and the request denied.

59. In re Special Feb., 1975 Grand Jury, 662 F.2d 1232, 1238-39 (7th Cir. 1981), cert. granted sub nom. United States v. Baggot, 102 S. Ct. 2955 (1982) (No. 81-1938); In re April 1977 Grand Jury Proceedings, 506 F. Supp. 1174, 1181 (E.D. Mich. 1981); In re 1978-1980 Grand Jury Proceedings, 503 F. Supp. 47, 48 (N.D. Ohio 1980).

60. 662 F.2d 1232 (7th Cir. 1981), cert. granted sub nom. United States v. Baggot, 102 S. Ct. 2955 (1982) (No. 81-1938). 
that it is 'preliminarily to' a judicial proceeding."61 Even if an IRS audit uncovers a tax deficiency, the court reasoned, the taxpayer may choose to pay the assessed deficiency rather than challenge it in a subsequent judicial proceeding. Thus, these two contingencies-whether the IRS would uncover a deficiency, and whether the taxpayer would challenge it-brought the disclosure request outside the ambit of the "preliminarily to" requirement. ${ }^{62}$

There are two problems with the Seventh Circuit's approach. First, it does not adequately distinguish the line of cases beginning with Rosenberry, which permits disclosure to bar association and police disciplinary bodies. ${ }^{63}$ Each of those cases presents the same dual contingency found in Baggot: the investigating authority may conclude there has been no wrongdoing, or the subject of the investigation may not contest the adverse action. ${ }^{64}$ Second, the Baggot decision presents the IRS with a "Catch-22": the taxpayer's assertion that he will not litigate any deficiency that is determined becomes the reason for denying the IRS disclosure of information necessary to determine the tax deficiency. ${ }^{65}$

Perhaps recognizing these problems, other courts have granted IRS requests identical to those denied in Baggot. ${ }^{68}$ In In re Judge Elmo B.

61. 662 F.2d at 1239 .

62. Concern about the likelihood of a subsequent judicial proceeding has led one court to consider a wide range of variables. In a case involving General Motors' tax liability, In re April 1977 Grand Jury Proceedings, 506 F. Supp. 1174, 1181 (E.D. Mich. 1981), the court's denial of an IRS disclosure request rested on (i) uncertainty about whether a deficiency would be proposed, (ii) the history of non-litigation between General Motors and the IRS, (iii) the financial advantages to General Motors in negotiating a settlement, (iv) the unmanageability of litigation about this particular area, and (v) the undesirability of litigation from General Motors' public relations standpoint.

63. See supra note 50 .

64. The court's effort at distinguishing the case from Jachimowski v. Conlisk, 490 F.2d 894 (7th Cir. 1973) (disclosure to Chicago police board) and In re Disclosure of Testimony, 580 F.2d 281 (8th Cir. 1978) (disclosure to bar and judicial disciplinary bodies) is unsuccessful. The court notes the "quasi-judicial" administrative hearing present in Conlisk-a policeman could appear with counsel, present witnesses and evidence, cross-examine witnesses, and obtain a record of the hearing-and states: "In the present case we have no comparable situation." Baggot, 662 F.2d at 1239. The "quasijudicial" nature of the hearing, however, was not the basis of the Conlisk court's determination that the hearing was preliminary to a judicial proceeding; rather the court looked at the entire "statutory scheme involved" and determined that judicial review was "plainly contemplate[d]." Conlisk, 490 F.2d at 897. The Baggot court never explains why judicial review of an IRS tax assessment is less plainly contemplated than judicial review of a police board's disciplinary action. As for its attempt to distinguish Disclosure of Testimony, the Baggot court merely states that the proceedings involved in that case were "designed to culminate in a judicial proceeding," without explaining why the IRS tax assessment fails to meet that standard. 662 F.2d at 1239.

65. Ruwe Statement, supra note 22.

66. See In re Judge Elmo B. Hunter's Special Grand Jury, 667 F.2d 724 (8th Cir. 1981); Petition of the United States for Disclosure of Grand Jury Matters (Miller Brewing Co.), 518 F. Supp. 163, 169 (E.D. Wisc. 1981), aff'd in part, rev'd in part, 687 F.2d 1079 (7th Gir. 1982); In re Grand Jury Investigation of Andrew Pentileakis, Misc. No. 79-30 (D.R.I. Sept. 14, 1979); In re 1974 Term Grand Jury Investigation, 449 F. Supp. 743 (D. Md. 1978); see also In re Grand Jury Subpoenas, 581 F.2d 1103, 1110 (4th Cir. 1978) (discussing disclosure criteria for civil tax enforcement), cert. denied, 440 U.S. 971 (1979). 
Hunter's Special Grand Jury, ${ }^{67}$ for example, the Eighth Circuit reversed a denial of an IRS disclosure request. The district court had found that the grand jury was used in good faith, that the material sought was relevant to the audit, and that the government had a particularized need for the information. ${ }^{88}$ The district court nevertheless denied the request because, like the Baggot court, it determined that judicial proceedings were too remote and speculative to satisfy the "preliminarily to" requirement. The Eighth Gircuit reversed, relying on the dissent in Baggot:

[T]he actual beginning of litigation is always an uncertain matter which may be deferred or even never begun for any of several reasons. If we read into the rule that the disclosure . . . must be preliminarily to a judicial proceeding bound to happen, we substantially are curtailing the plain language of the rule ....68

\section{Public Interest Approach}

In two well-publicized cases, courts eschewed the literal requirements of the "judicial proceeding" provision and released grand jury material without finding pending or contemplated judicial proceedings. Disclosure was justified as being in the public interest. These cases, which did not involve administrative agency disclosure requests, nonetheless highlight the general inadequacy of the "judicial proceeding" provision.

In In re Biaggi, ${ }^{70}$ the Second Circuit permitted disclosure of grand jury materials to the general public despite the absence of a foreseeable judicial proceeding. ${ }^{71}$ Mario Biaggi, a New York City mayoral candidate, sought release of his own grand jury testimony to rebut a New York Times article that reported Biaggi had invoked the Fifth Amendment in response to a number of questions. ${ }^{72}$ Writing for the majority, Chief Judge Friendly declared that insofar as the rule of secrecy was designed for the protection of witnesses, Biaggi had waived this protection by seeking disclosure. Judge Hays, dissenting, characterized the majority's decision as one based on 'the personal views of judges as to what 'the public interest' may

67. 667 F.2d 724 (8th Cir. 1981).

68. Id. at 725 n.2.

69. Id. at 727 (quoting In re Special Feb., 1975 Grand Jury, 662 F.2d 1232, 1241 (7th Cir. 1981) (Pell, J., concurring in part, dissenting in part) cert. granted sub nom. United States v. Baggot, 102 S. Ct. 2955 (1982) (No. 81-1938)).

70. 478 F.2d 489 (2d Cir. 1973).

71. Id. at $492-93$.

72. Biaggi initially sought to have a three judge panel review his testimony and answer a "precise question." The answer to this artfully phrased question "in all likelihood" would have suggested that Biaggi did not invoke the privilege. 478 F.2d at 494 (supplemental opinion). Much to his chagrin, however, the court publicly released an edited version of the transcript, which largely substantiated the New York Times story. 
require."73

Judge Sirica of the District Court for the District of Columbia followed a similar path a short time later with regard to the "Watergate" grand jury investigation. In In re Report \& Recommendation of June 5, 1972 Grand Jury, ${ }^{74}$ he ordered the release of a Watergate grand jury report to the House of Representatives for use in the House's impeachment investigation of President Nixon. ${ }^{7 b}$ Though the judge might have been able to justify the disclosure by applying the "judicial proceeding" provision, ${ }^{76}$ instead he stated that Rule 6(e) merely codified some circumstances under which grand jury materials could be released. Other circumstances, he argued, were governed by the common law that existed before the Federal Rules were adopted. ${ }^{77}$ Under this reading, failure to meet the "judicial proceeding" provision would not necessarily block disclosure when the public interest required it.

The Biaggi and Watergate grand jury opinions stand for something beyond the proposition that the "judicial proceeding" provision occasionally should yield to a compelling need for disclosure. They underscore the Rule's basic infirmity: its inability to balance properly the need for secrecy against the need for disclosure. Instead of providing the means by which courts can strike a proper balance, it has invited calculations concerning the likelihood of judicial proceedings. Neither the Rule's legislative history

73. Id.

74. 370 F. Supp. 1219 (D.D.C.), mandamus denied sub nom. Haldeman v. Sirica, 501 F.2d 714 (D.C. Cir. 1974).

75. The District of Columbia grand jury had delivered a sealed report accompanied by a transmittal memorandum that recommended the report be submitted to the House Judiciary Committee.

The House Judiciary Committee made a formal request for the materials. The President made no recommendation, and the Special Prosecutor urged that the report be forwarded. $370 \mathrm{~F}$. Supp. at 1221. The only objections to release came from several individuals who were indicted by the same grand jury and named in the report. Id. at 1221, 1231.

76. Judge Sirica himself analogized the House Committee to a grand jury. Id. at 1230. The analogy is apt: the House would return an "indictment" to the Senate, and the Senate then would try the case. It is well-established that disclosure of grand jury materials may be made to other grand juries. See, e.g., In re 1979 Grand Jury Proceedings, 479 F. Supp. 93, 96 (E.D.N.Y. 1980) (citing cases); In re Minkoff, 349 F. Supp. 154, 156 (D.R.I. 1972) (holding grand jury proceeding is a "judicial proceeding" for the purposes of rule 6(e)).

Some authorities have read the case as permitting disclosure pursuant to the "judicial proceeding" provision. See In re Grand Jury Investigation of Uranium Industry, 1979-2 Trade Cas. (CCH) II 62,798 , at 78,644 (D.D.C. 1979) (House Committee activity was "preliminar[y] to or in connection with a contemplated trial presided over by the Chief Justice of the United States-very much a judicial proceeding.").

On petition for mandamus of Judge Sirica's disclosure order, Judge MacKinnon based his concurrence in the majority's denial of the petition on the government's representation at oral argument that the House investigation was " preliminar[y] to [and] in connection with a judicial proceeding' . . . in which due process of law will be available." Haldeman v. Sirica, 501 F.2d 714, 717 (D.C. Cir. 1974) (MacKinnon, J., concurring in part, dissenting in part) (footnote omitted).

77. "The Court can see no justification for a suggestion that this codification of a ctraditional practice' should act, or have been intended to act, to render meaningless an historically proper function of the grand jury by enjoining courts from any disclosure of reports in any circumstance." $370 \mathrm{~F}$. Supp. at 1228 . 
nor sound public policy recommends such calculations. Moreover, no saving features compensate for this fundamental flaw: whether a disclosure request is "preliminarily to or in connection with a judicial proceeding" says little about the merits of the request. The secrecy policy can be served by devices better suited to the task.

\section{Recommendations}

The "judicial proceeding" provision represents a major obstacle to the efficient performance of administrative agencies' civil enforcement responsibilities. Adopted with little thought about the need for agency access to grand jury material, the provision has generated a confused and inconsistent body of caselaw. Reform is clearly needed. ${ }^{78}$ Disclosure should be permitted "when so directed by a court in the furtherance of justice."79

78. The Judicial Conference Advisory Committee on the Federal Rules of Criminal Procedure has proposed certain amendments to rule 6(e). See 91 F.R.D. 301 (1982). The Judicial Conference Standing Committee on Rules of Practice and Procedure invited public comment on these amendments. The authors of this Note submitted an earlier draft of the Note to the Judicial Conference and testified before the Conference in Washington, D.G., on February 10, 1982 (transcript on file with Yale Law Journal).

The exceptions to the general rule of secrecy proposed by the Judicial Conference read as follows in pertinent part (new matter is in italics):

(3) Exceptions.

....

(C) Disclosure otherwise prohibited by this rule of matters occurring before the grand jury may also be made-

(i) when so directed by a court preliminarily to or in connection with a judicial proceeding; or

(ii) when so directed by a court as to books, papers, documents or other objects, upon a showing which would suffice to compel disclosure of the objects if they had remained in the custody of the person from whom they were subpoenaed or otherwise obtained for use by the grand jury;

(iii) when permitted by a court at the request of the defendant, upon a showing that grounds may exist for a motion to dismiss the indictment because of matters occurring before the grand jury; or

(iv) when the disclosure is made by an attorney for the government to another federal grand jury.

If the court orders disclosure of matters occurring before the grand jury, the disclosure shall be made in such manner, at such time, and under such conditions as the court may direct.

91 F.R.D. at 302-03.

Exception (3)(C)(ii) represents a sound attempt to balance the need for secrecy against the need for disclosure. The materials delineated in this section will be released if the party requesting disclosure would have been able to compel disclosure of these items had the grand jury investigation never occurred and had the materials thus remained with their owners. The proposed amendments mean that "neither [the] person [who turned over materials to the grand jury], nor the person or agency seeking disclosure has gained a significant tactical advantage by virtue of the fact that the objects have come into the possession of the grand jury." Advisory Committee Note, 91 F.R.D. 305, 310 (1982); see also infra pp. 1633-35 (proposing similar standard).

The proposals, however, perpetuate use of the "judicial proceeding" provision for administrative agencies requesting transcripts and analyses. For all the reasons discussed in this Note this perpetuation of an inadequate phrase is unacceptable.

79. Incorporating this change, rule $6(e)$ would read (new matter is in italies):

Rule 6. The Grand Jury

.... 
Such an exception, derived from the common law that predated the Federal Rules, ${ }^{80}$ would enable administrative agencies to pursue efficiently their civil enforcement responsibilities without unduly compromising grand jury secrecy. The following guides to construction, suggested by the common law and present practice, would lend content to this exception.

\section{A. Documents}

Two reasons for maintaining secrecy after a grand jury investigation has ended are to encourage voluntary disclosure of information and to promote full and frank disclosure. Agency requests for subpoenaed documents, however, implicate neither of these reasons. By definition, a subpoenaed document is not voluntarily submitted; and once submitted, it can never yield anything less than full and frank disclosure. For these reasons, the guidelines covering requests for subpoenaed documents need not consider the need for grand jury secrecy. ${ }^{82}$ The guidelines must be attentive, however, to the possibilities of grand jury abuse and agency overreaching.

Agency disclosure requests covering subpoenaed documents should have to pass a two-part "good faith" test. First, the agency should demonstrate that the grand jury was not convened merely to further administrative discovery. ${ }^{\mathbf{8 2}}$ Courts should be particularly wary of cases in which the re-

(e) Recording and Disclosure of Proceedings.

(3) Exceptions. ...

(C) Disclosure otherwise prohibited by this rule of matters occurring before the grand jury may also be made-

(i) when permitted by a court at the request of the defendant, upon a showing that grounds may exist for a motion to dismiss the indictment because of matters occurring before the grand jury; or

(ii) when so directed by a court in the furtherance of justice.

$\ldots$

80. See supra note 32.

81. One reason for secrecy-protecting the innocent accused-is applicable even to subpoenaed documents. This reason, however, should not be dispositive in dealing with agency requests. Courts are free to edit the documents and to impose secrecy requirements on the agencies themselves in order to protect individuals. See infra pp. 1639-40.

82. In cases in which the grand jury issues an indictment, this requirement is easily met. See In re July 1973 Grand Jury, 374 F. Supp. 1334, 1337 (N.D. Ill. 1973) (allowing disclosure and noting that "the fact that the grand jury has already returned multiple-count indictments . . . indicates that there has been no perversion of grand jury processes"); see also In re Grand Jury Subpoenas, 581 F.2d 1103, 1110 (4th Cir. 1978) ("[T]he government should be required to demonstrate its bona fides prior to obtaining a [disclosure] order. This showing is particularly important where the grand jury fails to return an indictment. In such case, the likelihood of improper use of the grand jury process is substantially greater. ..."), cert. denied, 440 U.S. 971 (1979).

When the grand jury does not issue an indictment, the requesting agency should have to demonstrate that the criminal investigation was not a mere subterfuge for discovery. Cf. In re April 1956 Term Grand Jury, 239 F.2d 263 (7th Cir. 1956) (denying disclosure because grand jury subpoenas were being used by Treasury Department to obtain books and records that could not otherwise be obtained in civil investigation); United States v. Doe, 341 F. Supp. 1350, 1351 (S.D.N.Y. 1972) (denying disclosure because purpose of grand jury investigation was "ab initio the exploration of 
questing agency also assisted in the grand jury investigation because of the danger that the assisting agency used the grand jury as an investigative arm. ${ }^{83}$ Second, the agency should demonstrate that the request falls within its prescribed investigative boundaries. Unlike grand jury subpoenas, which are virtually immune from judicial challenge, agency subpoenas must meet four requirements before they will be enforced by a court: (i) the inquiry must fall within the authority of the agency, ${ }^{84}$ (ii) the demand must not be too indefinite, ${ }^{85}$ (iii) the information requested must be "reasonably relevant," ${ }^{88}$ and (iv) the information must not be privileged. ${ }^{87}$ An agency should be refused access under Rule $6(\mathrm{e})$ to documents that it would otherwise be unable to obtain using its own investigative powers. ${ }^{88}$ To permit broader disclosure would be to turn the grand jury into an

possible civil claims").

83. See generally Note, supra note 20, at 178-82 (noting subversion of congressional policy and threat to individual liberty resulting from agency direction of grand jury investigation). In cases in which the requesting agency was uninvolved in the grand jury investigation (e.g., requests from nonassisting federal and state agencies), the bad faith issue will seldom arise. For a full discussion of how use of a type of "good faith" test lessens the risk of grand jury abuse, see Note, supra note 33, at 1683-88.

84. See Administrative Procedure Act § 6(b), 5 U.S.G. § 555(c) (1976) ("Process, requirement of a report, inspection, or other investigative act or demand may not be issued, made, or enforced except as authorized by law.").

A court may also refuse to enforce a subpoena if an investigation was undertaken in bad faith, for example, for the purposes of harassment. See United States v. Powell, 379 U.S. 48, 58 (1964).

85. This requirement aims to prevent agencies from engaging in "fishing expeditions." See United States v. Morton Salt Co., 338 U.S. 632, 641-42 (1950). A subpoena, therefore, must adequately describe the materials sought, but this description is "variable in relation to the nature, purposes and scope of the inquiry." Oklahoma Press Publishing Co. v. Walling, 327 U.S. 186, 209 (1946). For example, in Westside Ford, Inc. v. United States, 206 F.2d 627, 629 (9th Cir. 1953), the Ninth Circuit upheld a lower court ruling enforcing a subpoena issued by the Office of Price Stabilization requiring "documents relating to all sales of new automobiles and services performed thereon" during a designated period. The court declared:

A wide range in investigation is necessary where, as here, the ceiling price regulations are exceedingly complex and the possibilities of violation or evasion so unlimited that the precise manner of violation cannot ordinarily be known or even suspected in advance. In such a case, there is no impossible requirement of meticulous pinpointing of narrow objectives and subjects of investigation.

Id. at 631 .

Courts have narrowed or refused to enforce subpoenas, however, when compliance would be unduly burdensome. See United States v. Associated Merchandising Corp., 261 F. Supp. 553 (S.D.N.Y. 1966) (narrowing FTC subpoena requiring inspection of two million documents and more than ten man-years of work).

86. Detweiler Bros. v. Walling, 157 F.2d 841, 843 (9th Cir. 1946), cert. denied, 330 U.S. 819 (1947). The relevancy requirement is closely related to the specificity requirement. See K. DAVI, ADMINISTRATIVE LAW TREATISE § 3.06, at 188-89 (1958).

87. The Fifth Amendment privilege against self-incrimination may be invoked if criminal sanctions may be applied. This privilege, however, will be unavailable for records of corporations and other organizations, for some records that are required by law, and for witnesses whose testimony is compelled and who, in return, are granted immunity. See K. DAVIS, supra note 86, § 3.07.

In some instances, both a common law privilege and the Fifth Amendment may be relevant in an enforcement action. See Fisher v. United States, 425 U.S. 391, 402-05 (1976) (discussing relationship between Fifth Amendment privilege and common law attorney-client privilege).

88. See United States v. Monsour, 508 F. Supp. 168, 169-70 (W.D. Pa. 1981) (demonstration of IRS subpoena authority is predicate for rule 6(e) disclosure). 
investigative arm of the administrative agency.

Disclosure of documents that were voluntarily submitted to the grand jury jeopardizes future voluntary submissions. Therefore the "good faith" test should be supplemented by a demonstration of "compelling need." Under a "compelling need" test, similar to that developed in the next section, courts would weigh the interest in encouraging voluntary submissions against the importance of access to the documents.

\section{B. Testimony}

Unlike requests for documents, agency disclosure requests covering testimony always implicate one reason for grand jury secrecy, encouraging full and frank disclosure. Requests covering volunteered testimony, moreover, jeopardize the additional policy of encouraging future voluntary appearances.

For these reasons, in addition to satisfying the "good faith" test, 89 an agency seeking disclosure of testimony should have to demonstrate a "compelling need" for that testimony. This test calls for a balancing of the two possible interests in secrecy against the importance of access to the testimony. The showing of "compelling need" should be made with particularity, so that only needed portions of a witness's testimony are released. $^{\mathbf{9 0}}$

89. In fact, the second branch of the "good faith" test may prove impossible to apply. Though an agency may be able to demonstrate that it could use its subpoena power to compel testimony from a grand jury witness, it could never prove that the substance of the testimony elicited at an administrative hearing would be the same as that elicited in the coercive atmosphere of the grand jury room.

90. In this sense, the existence of a pending judicial proceeding might count as a plus for the requesting agency. It would tend to focus the agency's request for disclosure and lead to greater specificity in the request. See supra note 17 (giving examples of particularized requests for witness testimony for use in judicial proceedings); see also supra note 6 (discussing particularity requirement).

Furthermore, the "compelling need" test for administrative agencies should be less stringent than the test for private litigants. Disclosure to government agencies in the furtherance of their statutory duties always entails an offsetting benefit to the public. United States v. Saks \& Co., 426 F. Supp. 812, 815 (S.D.N.Y. 1976) (noting additional public policy considerations favoring disclosure when request made by "government agency empowered to enforce the federal laws"); see also supra note 17 (discussing lower standard of need for agency requests in some district courts). Such a policy of offsetting public benefit may be seen to underlie disclosure commonly granted in bar committee and police disciplinary cases. See, e.g., United States v. Sobotka, 623 F.2d 764, 767 (2nd Cir. 1980) ("A second factor which we think reduces the burden of the Committee here is that disclosure is not simply sought by a private person for use in a judicial proceeding but rather by 'an independent public body charged with the performance of a public duty in a wholly disinterested and impartial manner.' "); Jachimowski v. Conlisk, 490 F.2d 894, 898 (7th Cir. 1973) ("maintenance of police integrity and credibility" supports disclosure of testimony by policemen to police board).

In addition, strict statutory requirements prevent the agency from making further disclosure. See Advisory Committee Note on Proposed Amendment to Rule 6(e), 91 F.R.D. 305, 313 (1982). For an example of such a statutory restriction, see I.R.C. $\$ 6103$ (West 1982) (regarding limits on disclosure of tax return information).

Disclosure to private litigants generally benefits only private parties, while compromising the public interest in maintaining grand jury secrecy. Sometimes, however, litigation by private parties may be an important supplement to agency regulatory activities. See, e.g., Cannon v. University of Chicago, 
Evidence of "compelling need" might include a showing of significant time and money savings. For example, if a grand jury investigation involved numerous witnesses, the agency might demonstrate the cost of locating, subpoenaing, and interrogating all the witnesses. ${ }^{91}$ Preventing a significant threat to the public health or safety would also constitute a compelling reason to release grand jury testimony. ${ }^{92}$ Finally, the "compelling need" test might be met if a witness became unavailable.

\section{Analyses}

Agency requests for analyses based solely upon subpoenaed documents should be subject only to the "good faith" test. Similarly, analyses based solely upon testimony or volunteered documents should be subject to the "good faith" and "compelling need" tests.

Many analyses, however, are based upon both documents and testimony. An agency seeking such analyses could ask the court to edit out the references to testimony and volunteered documents, and obtain the edited analyses through the use of the "good faith" test. If the analyses could not be edited satisfactorily without using this evidence, the agency would also have to meet the "compelling need" test.

\section{Opportunity to Oppose a Disclosure Request}

Courts also must determine whether Rule 6(e) hearings should be ex parte or adversarial. In 1977, Congress indicated that administrative agency requests for disclosure should be heard "ex parte so as to preserve, to the maximum extent possible, grand jury secrecy." ${ }^{\text {"3 }}$ Nonetheless recent

441 U.S. 677, 703-08 (1979) (private cause of action under Title IX will promote statutory purpose of eradicating sex discrimination); J.I. Case Co. v. Borak, 377 U.S. 426, 432 (1964) (private enforcement of proxy rules a "necessary supplement" to Securities and Exchange Commission action). Yet, while some courts have lowered the standard of "need" required of agencies in rule 6(e) requests, see supra note 17, no court has lowered the need standard for private litigants seeking disclosure pursuant to lawsuits that may supplement agency enforcement. Though beyond the scope of this Note, the same rationale that supports lowering the "need" standard for administrative agencies may also support softening the "need" requirement for some private litigants.

91. In In re Judge Elmo B. Hunter's Special Grand Jury, 667 F.2d 724, 726 (8th Cir. 1981), for example, the district court found that disclosure "would result in an enormous savings of taxpayer dollars and time and effort by the government."

92. In United States v. Young, 494 F. Supp. 57, 62-63 (E.D. Tex. 1980), for example, the court noted "the importance of an investigation by an administrative licensing agency into the qualifications of a physician who has pleaded guilty to drug charges." Disclosure to the agency was denied nonetheless. Id. at 65.

93. S. REP. NO. 354, 95th Cong., 1st Sess. 8, reprinted in 1977 U.S. CODE CONG. \& AD. NEWS $527,532$.

The Judicial Conference Advisory Committee's proposed amendments, see supra note 78, codify this legislative history by mandating that requests be heard ex parte when "the petitioner is the government and is seeking disclosure for its own use." 91 F.R.D. 301, 303 (1982). The Advisory Committee's Note explains the justification for hearing government disclosure requests ex parte by pointing out that internal regulations limit further disclosure of information disclosed to the govern- 
decisions permit parties to oppose agency requests for disclosure. ${ }^{94}$

As Congress recognized, allowing adversarial hearings in connection with Rule 6(e) requests could compromise grand jury secrecy. Because an agency seeking disclosure would have to frame its request with "particularity," by the grand jury. For example, the IRS might ask a court to release transcripts of the testimony of a grand jury witness for use in an enforcement action against the witness's employer. ${ }^{96}$ Permitting the employer to oppose such a request might lead to intimidation and subornation of the witness-employee and create a "chilling effect" on future witnesses. Moreover, the employer's appearance in court would offer no offsetting benefit: unless familiar with the testimony of the witness-employee, the employer would add little to a court's already considerable knowledge about the issues presented by a request for disclosure.

In other instances, however, adversarial proceedings can be beneficial. Indeed, allowing the witness-employee an opportunity to oppose the request for disclosure would not harm the interests protected by grand jury secrecy and might result in a more considered resolution of the issues involved.

This example makes clear that Rule 6(e) hearings need not be ex parte "to preserve, to the maximum extent possible, grand jury secrecy." Rather, some opposition should generally be permitted; the exact amount should depend on the materials requested and on whether the potential

ment. Advisory Committee Note, 91 F.R.D. 305, 313 (1982). Though this "fact" argues in favor of more freely allowing administrative agencies access to grand jury materials, it provides no support for the proposition that hearings should be held ex parte when no threat to secrecy exists.

94. See, e.g., Sells, Inc. v. United States, 642 F.2d 1184, 1192 (9th Cir. 1981) (noting congressional intent but permitting adversarial hearing in connection with IRS request for certain documents), cert. granted sub nom. United States v. Sells Eng'g, Inc., 102 S. Ct. 2034 (1982) (No. 811032); Petition of United States for Disclosure of Grand Jury Matters (Miller Brewing Co.), 510 F. Supp. 585, 586-87 (E.D. Wis. 1981) (permitting opposition to IRS request); In re April 1977 Grand Jury Proceedings, 506 F. Supp. 1174, 1176 (E.D. Mich. 1981) (noting that rule 6(e) requests are frequently heard ex parte, but allowing General Motors to oppose an IRS request without discussion). But see In re Grand Jury Matter, 682 F.2d 61, 66 (3d Cir. 1982) (invoking congressional intent to require disclosure request to be heard ex parte); In re December 1974 Term Grand Jury Investigation, 449 F. Supp. 743, 751 (D. Md. 1978) (same).

95. See supra note 6.

96. See Petition of United States for Disclosure of Grand Jury Matters (Miller Brewing Co.), 510 F. Supp. 585 (E.D. Wis. 1981) (involving IRS rule 6(c) request for employee testimony for use against corporate employer).

97. Cf., e.g., Petrol Stops Northwest v. United States, 571 F.2d 1127, 1130 (9th Cir. 1978) (corporate witnesses "vulnerable" to their corporate employers); Illinois v. Sarbaugh, 552 F.2d 768, 778 (7th Cir. 1977) ("W]hen a corporation receives disclosure of its employee's grand jury testimony, disclosure has been made to the most likely source of retaliation."); In re Cement-Concrete Block, 381 F. Supp. 1108, 1110 (N.D. Ill. 1974) (preserving grand jury secrecy in order to lessen witness's fear of retaliation has "special relevancy" when witnesses are employees or officers of potential defendants). 
adverse party has had access to these materials. ${ }^{98}$

Grand jury witnesses should always be notified of and permitted to oppose requests for transcripts of their testimony, or analyses based on that testimony. ${ }^{99}$ If the witness is not the target of the investigation, providing the target with notice and an opportunity to be heard would be appropriate only if the target has already had access to that testimony, or those analyses. ${ }^{100}$

Notice of and an opportunity to oppose a request for disclosure, however, should always be given to a target when the request is for subpoenaed documents or for analyses based on subpoenaed documents, whether provided by the target or third parties. ${ }^{101}$ Third parties who provided documents to the grand jury should also be notified and given an opportunity to oppose disclosure of these materials. ${ }^{102}$ Adversarial presentation here would contribute to a full consideration of the issues as well as a feeling of fairness, and not jeopardize grand jury secrecy.

It is important to note that even if the proceedings are ex parte, and the agency gains access to the grand jury materials, the target of the investigation is not precluded from later challenging the agency's actions. ${ }^{103}$

98. See In re Doe, 537 F. Supp. 1038, 1041-42 (D.R.I. 1982) (ex parte issue should be determined on case-by-case basis).

99. See Jachimowski v. Conlisk, 490 F.2d 894 (7th Cir. 1973) (permitting policemen to challenge disclosure of their grand jury testimony for use in disciplinary proceedings against them); In re Holovachka, 317 F.2d 834 (7th Cir. 1963) (allowing witness to oppose request for disclosure of his grand jury testimony); Petition of United States for Disclosure of Grand Jury Matters (Miller Brewing Co.), 510 F. Supp. 585 (E.D. Wis. 1981) (allowing witnesses to oppose IRS request for disclosure of their testimony).

100. Cf., e.g., Petrol Stops Northwest v. United States, 571 F.2d 1127, 1130 (9th Cir. 1978) (need for secrecy "limited" when corporate employer opposing disclosure of employee's testimony has in its possession the desired testimony); In re Cement-Concrete Block, 381 F. Supp. 1108, 1110 (N.D. Ill. 1974) (policy behind secrecy rule "partially vitiated" because party opposing disclosure has previously inspected requested transcripts); Connecticut v. General Motors Corp., 1974-2 Trade Cas. (CCH) T 75,138, at 97,080 (N.D. Ill. 1974) (as party opposing rule 6(c) disclosure had access to requested transcripts, "[w]hatever secrecy would normally attach to them has in effect already been abrogated").

101. Requests for documents that were submitted voluntarily or for analyses based on such materials raise concerns about discouraging future voluntary submissions. See supra pp. 1634-35. Hence, targets generally should not be permitted to oppose requests for those materials.

102. See In re Doe, 537 F. Supp. 1038, 1042 (D.R.I. 1982) (standing to object given to owners of documents "inasmuch as these persons are already aware of . . . the documents' contents"). In addition, third parties or targets ought to be permitted to move that disclosure proceedings be held in camera on grounds that a request covers sensitive materials. Cf. Petition of United States for Disclosure of Grand Jury Matters (Miller Brewing Co.), 510 F. Supp. 585, 588 (E.D. Wis. 1981) (rejecting Miller's request to view grand jury materials subpoenaed from Miller's largest competitor, because "[c]oncern over competitors viewing sensitive information is so great in this industry").

103. Evidence improperly obtained from a grand jury may be suppressed at subsequent civil proceedings. See, e.g., In re April 1977 Grand Jury Subpoenas, 584 F.2d 1366, 1370 (6th Cir. 1978) (en banc), cert. denied, 440 U.S. 934 (1979); In re Grand Jury, 583 F.2d 128, 131 (5th Cir. 1978) (per curiam); In re Grand Jury Subpoenas, 581 F.2d 1103, 1110 n.16 (4th Cir. 1978), cert. denied, 440 U.S. 971 (1979); Coson v. United States, 533 F.2d 1119, 1120 (9th Cir. 1976) (per curiam); Cohen v. Commissioner, 42 T.C.M. (CCH) 312, 322-24 (1981). 


\section{E. Court Orders}

Courts should disclose only those materials that have met the "good faith," and if appropriate, the "compelling need" guidelines. Courts should also carefully edit materials before release in order to minimize incursions on grand jury secrecy. ${ }^{104}$

In addition to tailoring disclosure orders as narrowly as possible, courts should impose the following four requirements on an agency's subsequent use of disclosed grand jury materials:

1) The agency should not give grand jury material to private parties or other agencies. If another agency requires the material, it should have to request disclosure from the court separately.

2) The receiving agency should not publicize disclosed information, except at administrative hearings, where the target is given an opportunity to challenge the information. ${ }^{105}$ This requirement would reduce the problems that are associated with grand jury reports. ${ }^{106}$

3) Disclosed material should be used only for the purposes stated in the disclosure request. If the agency wishes to use the material for another purpose, it should have to return to the court and obtain permission. ${ }^{107}$

4) Courts should specify a time period during which the agency must

104. In In re Disclosure of Testimony, 580 F.2d 281, 284 (8th Cir. 1978), for example, the court ordered disclosure in two stages to four administrative bodies investigating official misconduct. First, after reading the entire grand jury transcript, which consisted of testimony of more than 100 witnesses, the court provided the movants with the names and addresses of those grand jury witnesses that testified about areas over which the individual applicants had jurisdiction.

Following the release of these names and addresses, the movants interviewed the named witnesses and provided the court with statements taken from each witness. The court compared these statements with the testimony of the witnesses before the grand jury and found that two of the witnesses had refused to make statements, five had given statements which contained material omissions of information given to the grand jury in their testimony, and one had furnished a statement substantially at odds with his grand jury testimony. Accordingly, the court authorized the further disclosure of copies of specified pages from the grand jury transcript that contained testimony either omitted from or significantly at variance with statements made to the applicants or testimony of persons who refused to give any statement to the applicants.

105. There exists sufficient caselaw to alleviate concerns that the Freedom of Information Act (FOIA), 5 U.S.C. $§ 552$ (1976), may force agencies to release grand jury materials that should not be made available to the public. See, e.g., Valenti v. United States Dep't of Justice, 503 F. Supp. 230 (E.D. La. 1980) (grand jury materials, although in agency's possession, were court records and therefore not covered by FOIA); Hiss v. Department of Justice, 441 F. Supp. 69 (S.D.N.Y. 1977) (holding that FOIA does not affect grand jury secrecy); Chamberlain v. Alexander, 419 F. Supp. 235 (S.D. Ala. 1976) (FOIA exemption covers grand jury testimony), aff'd in part, rev'd in part, 589 F.2d 827 (5th Cir. 1979), cert. denied, 444 U.S. 842 (1980).

106. See supra pp. 1623-25.

107. For example, if the IRS obtains a disclosure order to facilitate a tax investigation against Smith, it cannot also use the information garnered in this manner against Jones. To proceed against Jones with these materials, the agency must seek a new court order. Though establishing "good faith" may involve only a pro forma recitation of the facts earlier found sufficient in the Smith request, "compelling need" can be measured only with reference to the new use to which the agency wishes to put the materials. Moreover, the agency may have to notify Jones and give him an opportunity to oppose the new use of the materials. See supra pp. 1636-38. 
initiate an enforcement proceeding pursuant to its Rule 6(e) request. If a proceeding is not instituted within that period, the grand jury material and any copies thereof should be returned to the court. Disclosed material should also have to be returned after it is used in a civil enforcement proceeding. A new court order would be required for any subsequent use. This guideline will prevent Rule 6(e) disclosures from contributing to "dossiers" with which administrative agencies might harass the targets of their investigations. ${ }^{108}$

\section{Conclusion}

Rule 6(e) poses barriers to administrative agency access to grand jury material that are suggested neither by the legislative history of the Rule nor by the policies that underlie grand jury secrecy. Furthermore, such barriers hamper the efforts of administrative agencies to carry out their mandated civil enforcement responsibilities. The guidelines in this Note remain attentive to the policies that underlie grand jury secrecy but at the same time recognize that, on occasion, public policy argues strongly in favor of disclosure.

108. Cr. Note, supra note 20 , at 179 (citing several instances of use of administrative agencies for harassment of political enemies during Nixon Administration). 